\title{
COMPARSION OF MULTISPECTRAL REFLECTANCE WITH DIGITAL COLOR IMAGE IN ASSESSING THE WINTER WHEAT NITROGEN STATUS
}

\author{
Liangliang Jia ${ }^{1,2}$, Xinping Chen ${ }^{1, *}$, Minzan $\mathrm{Li}^{3}$, Zhenling Cui ${ }^{1}$, Fusuo \\ Zhang ${ }^{1}$ \\ ${ }^{1}$ College of Resources and Environmental Sciences, China Agricultural University, Beijing, \\ 100094, China \\ ${ }^{2}$ Institute of Agricultural Resources \& Environment, Hebei Academy of Agriculture and \\ Forestry Sciences, 050051, Shijiazhuang, China \\ ${ }^{3}$ Key lab of Precision Agriculture, China Agricultural University, Beijing, 100083, China \\ * Corresponding author, Address: College of Resources and Environmental Sciences, China \\ Agricultural University, Beijing 100094, Beijing, P.R. China, Tel: +86-10-62733454, Fax: \\ +86-10-62731016, Email: chenxp@cau.edu.cn
}

Abstract: Previous researches have shown that the digital image color intensity could reflect the crops $\mathrm{N}$ status, but there is little information about the comparision of spectrum reflectance in the visible bands with the digital imagery color intensities. A field experiment was conducted to compare the wheat canopy reflectance at visible bands $(400-700 \mathrm{~nm})$ at shooting stage with near ground digital image to detect $N$ deficiencies. Single color bands of $R, G, B$ and ratio indices of $\mathrm{G} / \mathrm{R}, \mathrm{G} / \mathrm{B}, \mathrm{R} / \mathrm{B}, \mathrm{R} /(\mathrm{R}+\mathrm{G}+\mathrm{B}), \mathrm{G} /(\mathrm{R}+\mathrm{G}+\mathrm{B})$ and $\mathrm{B} /(\mathrm{R}+\mathrm{G}+\mathrm{B})$, which derived from digital image and spectral measurments, were regressed with wheat $\mathrm{N}$ status. The $\mathrm{R}, \mathrm{G}, \mathrm{G} / \mathrm{B}, \mathrm{R} / \mathrm{B}, \mathrm{R} /(\mathrm{R}+\mathrm{G}+\mathrm{B})$ and $\mathrm{G} /(\mathrm{R}+\mathrm{G}+\mathrm{B})$ all had negative correlations, while the $G / R$ and $B /(R+G+B)$ indices had positive correlations, with plant $\mathrm{N}$ status. For the $\mathrm{B}$ band, the digital image analysis data got positive correlations while the spectral measurements got negative correlations. With higher correlation coefficient than other indices, the $\mathrm{R} /(\mathrm{R}+\mathrm{G}+\mathrm{B})$ was the best index in this research. Considering the easiness of getting digital images and the accurate prediction of crops $\mathrm{N}$ status, the digital image analysis method seems to be a better way for in field plant $\mathrm{N}$ status evaluation.

Keywords: Spectrum reflectance; Image analysis; Color intensity; Winter wheat

Please use the following format when citing this chapter:

Jia, L., Chen, X., Li, M., Cui, Z. and Zhang, F., 2009, in IFIP International Federation for Information Processing, Volume 294, Computer and Computing Technologies in Agriculture II, Volume 2, eds. D. Li, Z. Chunjiang, (Boston: Springer), pp. 1161-1170. 


\section{INTRODUCTION}

Nitrogen is one of the most important plant nutrients for winter wheat production and application of $\mathrm{N}$ fertilizer can help farmers obtaining higher yields. But the $\mathrm{N}$ over fertilization had become a common problem on the North China Plain and resulted low $\mathrm{N}$ use efficiency and increased the possibility for groundwater nitrate contamination (Zhao et al., 2006; Chen et al., 2000).

Traditional methods of estimating in-season optimum $\mathrm{N}$ requirements for wheat are based on soil Nmin testing (Wehrmann et al., 1988), tissue $\mathrm{N}$ concentrations (Vaughan et al., 1990, Tyner and Webb, 1946), and stem sap nitrate concentration (Zhen and Leigh, 1990). But all these methods require multiple and destructive sampling during the crop growth, can be expensive and time consuming (Blackmer and Schepers, 1995). Chlorophyll meter provides a rapid and inexpensive way of assessing $\mathrm{N}$ status of crops without destruction, but it could only test a small number of leaves and lead to uncertainty in characterizing variability within large fields (Fox et al., 1994; Smeal and Zhang, 1994).

Remote sensing provides a cheap and quick solution to assess the growing conditions or crops than traditional analysis methods. Spectrum reflection of crops canopy have been shown its advantage in assessing $\mathrm{N}$ status of crops (Graeff et al., 2001; Filla et al., 1995; Gitelson and Merzlyzk, 1994). Some indices such as NDVI (Normalized Difference Vegetation Index, Rouse et al., 1973), RVI (Ratio Vegetation Index, Jordan, 1969), and GNDVI (Green Normalized Vegetation Index, Gitelson and Merzlyzk, 1997) have been developed to analyze the reflection of crop canopy. These vegetation indices have been widely used in estimating the crops growth status and nutrient status. On the other hand, remote sensing via aerial color or CIR photography has been used in detecting the $\mathrm{N}$ status or characterizing $\mathrm{N}$ requirements of crops (Sripada et al., 2005, 2006; Flowers et al., 2003; Sharpf and Lory, 2002; Blackmer and Schepers, 1996) by utilizing the ditital number of canopy image for R (red), G (green) and B (blue). With the quick development of digital camera image acquisition technology, some researches have used digital camera to analyze the crops nutrients disorder (Jia et al., 2004a; Graeff et al., 2001), vegetation coverage (Lukina et al., 1999), tiller density (Adamsen et al., 1999) and $\mathrm{N}$ fertilizer recommendation (Jia et al., 2004b) The calculated G/R (Adamsen et al., 1999) or $\mathrm{R} /(\mathrm{R}+\mathrm{G}+\mathrm{B}$ ) (Jia et al., 2004a) ratios showed good correlations with plant total shoot $\mathrm{N}$ concentration, SPAD chlorophyll meter readings, or the predicted $\mathrm{N}$ supply rates.

The digital image covers the spectrum reflection in the visible bands ranging from $400 \mathrm{~nm}$ to $700 \mathrm{~nm}$. It is still no comparsion of the correlations for $R, G, B$ and their combinations $G / R, G / B, R / B$ or $G /(R+G+B)$, 
$\mathrm{R} /(\mathrm{R}+\mathrm{G}+\mathrm{B})$ and $\mathrm{B} /(\mathrm{R}+\mathrm{G}+\mathrm{B})$ with the spectrum reflection of crops canopy, and which one could be used in crops $\mathrm{N}$ status detection. In this context, the objective of this study was to compare the methods of spectral reflectance in the visible part of the spectrum with the digital image analysis to make plant $\mathrm{N}$ status assessment.

\section{MATERIALS AND METHODS}

\subsection{Experiment background}

A field experiment comprised a winter wheat/summer maize double cropping system, which involved planting and harvesting of one wheat and one maize crop in one year, was conducted in Dongbeiwang Experiment Site, near Beijing, China since October 1999. The experiment was a 3 × 2 × 3 factorial split-split block experiment with four replications, which contained (i) three methods of irrigation, sub-optimal irrigation as a control, conventional irrigation as farmers' practice and optimized irrigation based on soil water measurement, as main plots of $60 \times 30 \mathrm{~m}$; (ii) two straw levels, with straw (straw recycling) and without straw (without straw recycling), as sub-plots of $60 \times 15 \mathrm{~m}$, and (iii) three levels of $\mathrm{N}$ application as sub-subplots of $20 \times 15 \mathrm{~m}$ (control, farmer's $\mathrm{N}$ fertilization and 'optimized' $\mathrm{N}$ fertilization). Farmer's $\mathrm{N}$ fertilization consisted of $150 \mathrm{~kg} \mathrm{~N}$ ha-1 applied as NH4HCO3 before sowing and an additional $150 \mathrm{~kg} \mathrm{~N}$ ha-1 as urea at booting, which is typically practiced by local farmers. The optimized $\mathrm{N}$ fertilization treatment took the soil mineral $\mathrm{N}(\mathrm{Nmin})$ in the soil profile before sowing, at regreening and at booting, and yield goal into consideration to determine target $\mathrm{N}$ value (split for three growth stages).

The first crop in this experiment was summer maize, which was sown at June 1999 and harvested at Sept. 1999. From Oct. 1999 to Sep. 2004, five winter wheat/ summer maize rotations followed. In this study, all results were obtained in the 2003/2004 winter wheat growing season, totally 3 treatments with different $\mathrm{N}$ treatments but all with optimized irrigation and without straw recycling were selected in each of the 4 replicates (Table 1).

\subsection{Data collection and processing}

On shootingting stage of Apr. 25th, digital pictures of the winter wheat canopy were obtained with an Olympus E-20P digital damera. To work at a comparable solar angle and light intensity, all images were taken between 12 to 13 hour on cloudless day at $1.2 \mathrm{~m}$ above the ground and at an angle of $60^{\circ}$. 
The digital images of $2560 \times 1960$ pixels of 8 bit for red, green and blue were transferred in JPEG format to a computer and processed with Adobe Photoshop ${ }^{\circledR}$ to extract color information of the digital number of Red, Green and Blue. Ratio indices of $\mathrm{G} / \mathrm{R}, \mathrm{G} / \mathrm{B}, \mathrm{R} / \mathrm{B}, \mathrm{G} /(\mathrm{R}+\mathrm{G}+\mathrm{B})$ and $\mathrm{R} /(\mathrm{R}+\mathrm{G}+\mathrm{B})$ were calculated (Lukina et al., 1999; Scharpf and Lory, 2002; Jia et al., 2004).

Table 1 Soil mineral nitrogen (Nmin in $\mathrm{kg} / \mathrm{ha}$ ) at different wheat growth stage and $\mathrm{N}$ application rates $(\mathrm{kg} / \mathrm{ha})$ in the selected treatments at Dongbeiwang, Beijing, China

\begin{tabular}{lccc}
\hline \multicolumn{1}{c}{ Treatments $\dagger$} & No N & Conventional N & Optimized N \\
\hline Nmin before sowing $(0-90 \mathrm{~cm})$ & 19 & 398 & 47 \\
Basal mineral N fertilization & 0 & 150 & 0 \\
Nmin at regreening $(0-60 \mathrm{~cm})$ & 26 & 291 & 40 \\
Topdressing at regreening & 0 & 0 & 57 \\
Nmin at shooting $(0-90 \mathrm{~cm})$ & 13 & 554 & 42 \\
Total N applied before shooting & 0 & 150 & 57 \\
\hline
\end{tabular}

$\%$ Treatments fertilization background. No $N$ treatments, 1 crop growth season no $N$ fertilization; Conventional $N$, continuously 10 crop seasons with conventional high $N$ fertilization of $300 \mathrm{~kg} / \mathrm{ha}$ per crop season; Optimized $\mathrm{N}$, continuously $10 \mathrm{crop}$ seasons with optimized $N$ fertilization based on soil-plant analysis.

The wheat canopy hyper spectral reflectance measurements were conducted at the same day with digital image acquisition. A handheld ASD FieldSpec spectral radiometer with a range of 325-1075 nm and $1 \mathrm{~nm}$ resolution was used to measure the spectral reflectance of wheat canopy. Measurements were made 5 sites over each plot, looking straight down from $20 \mathrm{~cm}$ above the canopy. With a field view of $28^{\circ}$, the sensor viewed an area about $20 \mathrm{~cm}$ in diameter. Radiometer calibration was conducted before each measurement with a white panel. Data were obtained between 11 and 14 hour in order to have a stable solar angle and light intensity. $460 \mathrm{~nm}, 560 \mathrm{~nm}$ and $690 \mathrm{~nm}$ were selected as compared with Blue, Green and Red bands of digital image. Ratios of $G / R, G / B, R / B, G /(R+G+B)$ and $R /(R+G+B)$ were calculated.

Plant SPAD readings were taken with a Minolta SPAD®--502 chlorophyll meter on 21 April as an average of the first fully expanded leaves from 30 randomly selected plants per plot. The stem sap nitrate concentration of wheat was tested with a Reflect Meter (Merck Co., Darmstadt, Germany) at the same day. Above ground plant biomass was harvested in a $1 \mathrm{~m} 2$ sampling area per plot, dried to constant weight at $70^{\circ} \mathrm{C}$, and analyzed for total $\mathrm{N}$ using the Kjeldahl method. And at maturity three separate subsamples (each of size $3 \mathrm{~m} 2$ ) were harvested to determine grain yield for each plot. For analysis of soil Nmin at planting, regreening (156 days after sowing, DAS) and shooting (180 DAS), five cores were collected from each plot and pooled at 0 to $30 \mathrm{~cm}, 30$ to $60 \mathrm{~cm}$, and 60 to $90 \mathrm{~cm}$ depth intervals. All samples were dried and sieved, extracted with $0.01 \mathrm{~mol} \mathrm{~L}-1 \mathrm{CaCl} 2$ and 
analyzed for NH4+ and NO3- by continues flow analyzer TRAACS 2000 (Bran+Luebbe, 1996). Soil Nmin in 0-90 cm soil profile was tested at before sowing and shooting stage, but only $0-60 \mathrm{~cm}$ soil layer depth was tested at regreening stage.

\subsection{Data analysis}

Nitrogen effects were analyzed quantitatively by comparing the means of agronomic parameters and reflectance spectra of each treatment through Duncan's multiple range tests at a probability of 0.05 . Data sets of single band of $R$ (red), $G$ (green) and $B$ (blue) and ratio indices of $G / R, G / B$ and $\mathrm{R} / \mathrm{B}$, and normalized indices of $\mathrm{G} /(\mathrm{R}+\mathrm{G}+\mathrm{B}), \mathrm{R} /(\mathrm{R}+\mathrm{G}+\mathrm{B})$ and $\mathrm{B} /(\mathrm{R}+\mathrm{G}+\mathrm{B})$, which derived from digital image (near ground and aerial photography) or from the ASD FieldSpec spectral measurements, were regressed with plant $\mathrm{N}$ status parameters of chlohrophyll meter SPAD readings, upland biomass, sap nitrate concentration and total $\mathrm{N}$ content by using the SAS software (SAS Inst., 1990). Linear or nonlinear models were tested to fit the plot patterns and best-fit R2 values for the relationship.

\section{RESULTS}

\subsection{Nitrogen effects on $\mathbf{N}$ status and spectral reflectance of wheat at shooting stage}

Wheat growth was significantly affected by soil Nmin and $\mathrm{N}$ fertilizer application rate before shooting (Table 2). The plots with no $\mathrm{N}$ treatment were characterized by lower SPAD readings, above ground biomass, total $\mathrm{N}$ content and sap nitrate concentration. Optimized $\mathrm{N}$ treatments significantly lower than traditional $\mathrm{N}$ treatments in above ground biomass, total $\mathrm{N}$ concentration and plant sap nitrate concentration, but no difference was found in SPAD readings.

Table 2 Average SPAD readings, above ground biomass, total plant $\mathrm{N}$ content and plant sap nitrate concentration of winter wheat at shooting stage and grain yield at harvest

\begin{tabular}{ccccc}
\hline Treatments & SPAD reading & Biomass $(\mathrm{kg} / \mathrm{ha})$ & Total N Cont. (\%) & Stem sap nitrate Cont. $(\mathrm{mg} / \mathrm{kg})$ \\
\hline No N & $33.4 \mathrm{~b}^{*}$ & $1040 \mathrm{c}$ & $2.12 \mathrm{c}$ & $38 \mathrm{c}$ \\
Traditional N & $43.6 \mathrm{a}$ & $2149 \mathrm{a}$ & $3.58 \mathrm{a}$ & $3875 \mathrm{a}$ \\
Optimized N & $40.3 \mathrm{ab}$ & $1743 \mathrm{~b}$ & $3.26 \mathrm{~b}$ & $2176 \mathrm{~b}$ \\
\hline
\end{tabular}

*Values followed by different letters are significantly different at $P<0.05$. 
The $\mathrm{N}$ management effects were manifested in canopy reflectance. Spectral reflectance of wheat canopy under different $\mathrm{N}$ treatments measured at shooting stage (21 April, 2004) is shown in Figure 1. Reflectance decreased in the visible wavebands region with increasing $\mathrm{N}$ supply. Two reflectance peaks were found in $460 \mathrm{~nm}$ and $560 \mathrm{~nm}$ and an absorption valley was found in $690 \mathrm{~nm}$. The no $\mathrm{N}$ treatments had the higher reflectance percentage than those of optimized and traditional $\mathrm{N}$ treatments throughout the visible spectrum from $400 \mathrm{~nm}$ to $700 \mathrm{~nm}$. Reflectance from no-N treatment was significantly higher than those of optimized and traditional $\mathrm{N}$ treatments in 560 and $690 \mathrm{~nm}$. There were no differences of spectral reflectance between optimized and traditional $\mathrm{N}$ treatments in visible wavebands of 460, 560 and $690 \mathrm{~nm}$, but the spectral reflectance of optimized $\mathrm{N}$ treatment was higher than traditional $\mathrm{N}$-treatment (Table 3).

Table 3 Average reflectance (\%) at 460, 560 and $690 \mathrm{~nm}$ of wheat with different $\mathrm{N}$ treatments at shooting stage

\begin{tabular}{cccc}
\hline Treatments & $460 \mathrm{~nm}$ & $560 \mathrm{~nm}$ & $690 \mathrm{~nm}$ \\
\hline No N & $4.8 \mathrm{a}$ & $18.5 \mathrm{a}$ & $6.9 \mathrm{a}$ \\
Traditional N & $4.5 \mathrm{a}$ & $13.9 \mathrm{~b}$ & $4.3 \mathrm{~b}$ \\
Optimized N & $4.6 \mathrm{a}$ & $14.9 \mathrm{~b}$ & $4.6 \mathrm{~b}$ \\
\hline
\end{tabular}

*Values followed by different letters are significantly different at $P<0.05$
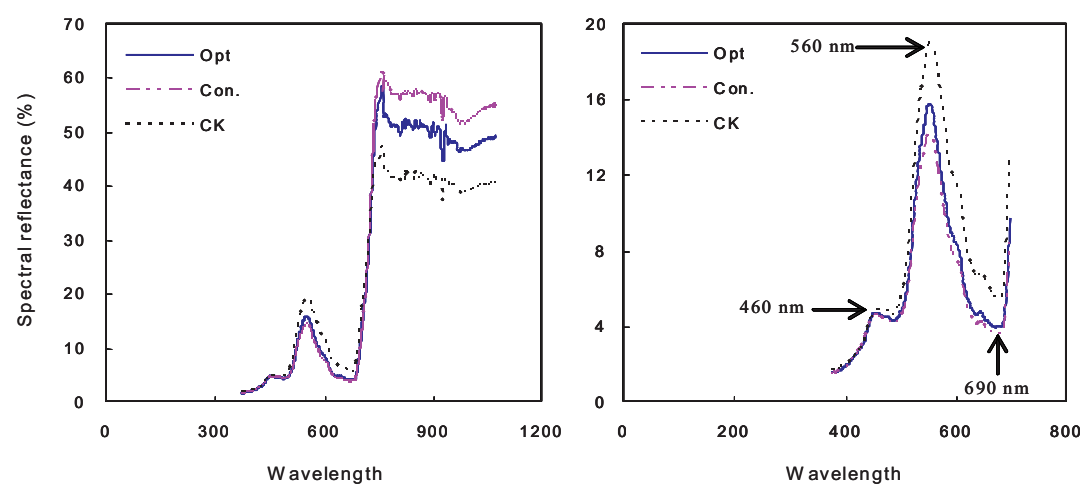

Figure 1 Wheat canopy reflectance with different $\mathrm{N}$ treatments at shooting stage

\subsection{Correlations of color intensity and ratio indices with with wheat $\mathbf{N}$ status}

Linear correlations were found to be the best correlation model between the color intensities and ratio indices with wheat $\mathrm{N}$ status at shooting stage. The correlation coefficients were listed in table 4. Significant linear correlations were found for single band of R, G and B with wheat N status at 
shooting stage. The $\mathrm{R}$ and $\mathrm{G}$ bands all had significant negative correlations while the $\mathrm{B}$ band had positive correlations with $\mathrm{N}$ status parameters for digital image. And the $\mathrm{B}$ band had negative correlations with plant $\mathrm{N}$ status for spectral measurement.

For the ratio indices, $\mathrm{G} / \mathrm{B}$ and $\mathrm{G} / \mathrm{R}$ had sigificant positive correlations with wheat $\mathrm{N}$ status while the $\mathrm{R} / \mathrm{B}$ had negative correlations both for digital image analysis and spectral measurement. The normalized indices of $\mathrm{R} /(\mathrm{R}+\mathrm{G}+\mathrm{B})$ and $\mathrm{B} /(\mathrm{R}+\mathrm{G}+\mathrm{B})$ had significant correlations with plant $\mathrm{N}$ status for both digital image and spectral measurements. But significant correlations for $\mathrm{G} /(\mathrm{R}+\mathrm{G}+\mathrm{B})$ were only found for digital image.

Table 4 Correlation coefficients of wheat $\mathrm{N}$ status parameters at shooting stage with digital image color intensity and various ration indices for near ground and aerial photography and spectral reflectance

\begin{tabular}{|c|c|c|c|c|c|c|c|c|c|}
\hline $\mathrm{r}$ & $\mathrm{R}$ & G & B & $\mathrm{G} / \mathrm{R}$ & G/B & $\mathrm{R} / \mathrm{B}$ & $\mathrm{R} /(\mathrm{R}+\mathrm{G}+\mathrm{B})$ & $\mathrm{G} /(\mathrm{R}+\mathrm{G}+\mathrm{B})$ & $\mathrm{B} /(\mathrm{R}+\mathrm{G}+\mathrm{B})$ \\
\hline \multicolumn{10}{|c|}{ Digital image analysis } \\
\hline SPAD & $-0.431^{*}$ & -0.370 & $0.842^{* *}$ & $0.508^{*}$ & $-0.807^{* *}$ & $-0.690^{*}$ & $-0.809^{* *}$ & $-0.794^{* *}$ & $0.825^{* *}$ \\
\hline Nitrate & $-0.762^{* *}$ & $-0.741^{* *}$ & $0.752^{* *}$ & $0.723^{* *}$ & $-0.780^{* *}$ & $-0.850^{* *}$ & $-0.892^{* *}$ & $-0.767^{* *}$ & $0.855^{* *}$ \\
\hline Biomass & $-0.738^{* *}$ & $-0.712^{* *}$ & $0.725^{* *}$ & $0.718^{* *}$ & $-0.784^{* *}$ & $-0.837^{* *}$ & $-0.869^{* *}$ & $-0.736^{* *}$ & $0.828^{* *}$ \\
\hline $\mathrm{N} \%$ & $-0.734^{* *}$ & $-0.704^{* *}$ & $0.846^{* *}$ & $0.712^{* *}$ & $-0.880^{* *}$ & $-0.880^{* *}$ & $-0.946^{* *}$ & $342^{* *}$ & $0.922^{* *}$ \\
\hline \multicolumn{10}{|c|}{ Spectral measurements by ASD FieldSpec } \\
\hline SPAD & $-0.820^{* *}$ & $-0.721^{* *}$ & $-0.480^{*}$ & $0.793^{* *}$ & $-0.679^{*}$ & $-0.679^{*}$ & $-0.824^{* *}$ & 0.203 & $0.669^{*}$ \\
\hline Nitrate & $-0.805^{* *}$ & $-0.795^{* *}$ & $-0.360^{*}$ & $0.625^{*}$ & $-0.899^{* *}$ & $-0.899^{* *}$ & $-0.733^{* *}$ & -0.241 & $0.859^{* *}$ \\
\hline Biomass & $-0.849^{* *}$ & $-0.846^{* *}$ & $-0.435^{*}$ & $0.637^{*}$ & $-0.828^{* *}$ & $-0.828^{* *}$ & $-0.730^{* *}$ & -0.234 & $0.867^{* *}$ \\
\hline N\% & $-0.892^{* *}$ & $-0.787^{* *}$ & -0.283 & $0.835^{* *}$ & $-0.894^{* *}$ & $-0.894^{* *}$ & $-0.909^{* *}$ & -0.066 & $0.937^{* *}$ \\
\hline
\end{tabular}

\section{CONCLUSION}

In this study, single bands of $R, G$ and $B$ with ration indices $G / R, G / B$, $R / B$ and normalize indices of $R /(R+G+B), G /(R+G+B)$ and $B /(R+G+B)$, which derived from data sets of digital image and spectral measurement, had been tested the correlations with wheat $\mathrm{N}$ status. And in this research, not only $\mathrm{G} / \mathrm{R}$ ratio (Adamasen et al., 1999), but also the $\mathrm{R} / \mathrm{B}, \mathrm{R} /(\mathrm{R}+\mathrm{G}+\mathrm{B})$ and $\mathrm{B} /(\mathrm{R}+\mathrm{G}+\mathrm{B})$ had good correlations with $\mathrm{N}$ status of wheat at shooting stage. The high correlations for digital image analysis indices with $\mathrm{N}$ status showed its potential be used in crops $\mathrm{N}$ status evaluation.

The digital image acquisition had the advantage of integrating a large sampling area and would involve less labor than the use of spectrum reflectance measurement for $\mathrm{N}$ management. And the correlations inconsistency also happened in the $\mathrm{B}$ band, which got high negative correlations with spectra testing, but positive correlations with near ground digital image. This was different with the previous research of nutrients deficiency plants reflect more light over the whold visible spectral bands 
(Al-Abbas et al., 1974). More researches should be conducted before definitive conclusion can be draw. And the higher correlation coefficient values of $R /(R+G+B)$ with wheat $N$ status for the digital camera and spectral reflectance suggested it maybe the best index in this research.

A shortcoming for digital image was not able to use the infrared spectrum reflectance from crops, more sensitive spectrum band to crop growth status, while lots of spectrum reflection indices have shown very useful in assessing $\mathrm{N}$ status of crops. The NIR spectral reflectance and the relative vegetation indices in this research had showed better correlations with $\mathrm{N}$ status than digital image (Table 5). But with the quick development of technology, the CCD digital camera now can directly record the NIR band. Considering the easiness and quickness of getting digital images and the accurate prediction of crops $\mathrm{N}$ status, the digital image seems to be a better way for in field plant $\mathrm{N}$ status assessment.

Table 5 Correlation coefficients between wheat $\mathrm{N}$ status parameters at shooting stage with NIR, NDVI, GNDVI, RVI derived from spectral reflectance of wheat canopy

\begin{tabular}{ccccc}
\hline $\mathrm{r}$ & $\mathrm{NIR}$ & $\mathrm{NDVI}$ & GNDVI & RVI \\
\hline SPAD & $0.757^{* *}$ & $0.828^{* *}$ & $0.811^{* *}$ & $0.850^{* *}$ \\
Nitrate & $0.849^{* *}$ & $0.863^{* *}$ & $0.910^{* *}$ & $0.881^{* *}$ \\
Biomass & $0.743^{* *}$ & $0.853^{* *}$ & $0.884^{* *}$ & $0.846^{* *}$ \\
N $\%$ & $0.907^{* *}$ & $0.958^{* *}$ & $0.950^{* *}$ & $0.929^{* *}$ \\
\hline
\end{tabular}

*Significant at $P<0.05 ; * *$ Significant at $P<0.01$

\section{ACKNOWLEDGEMENTS}

This research was financially supported by the Key Project of Eleventh Five-year National Plan (2006BAD02A15), Natural Science Foundation of China (Project number: 30571080), the Program for Changjiang Scholars and Innovative Research Team in University of China (IRT 0511).

\section{REFERENCES}

A. A. Gitelson, M.N. Merzlyak. Remote estimation of chlorophyll content in higher plant leaves. International Journal of Remote Sensing, 1997, 18: 291-298.

A. A. Gitelson, M.N. Merzlyak. Spectral reflectance changes associated with autumn senescence of Aesculus hippocastanum L. and Acer platanoides L. leaves. Spectral features and relation to chloropyll estimation. Journal of Plant Physiology, 1994, 143: 286-292.

A. H. Al-Abbas, R. Barr, J. D. Hall, F. L. Crane, M. F. Baumgardner. Spectra of normal and nutrient-deficient maize leaves, Agronmy Journal, 1974, 66: 16-20

B. Vaughan, K. A. Barbarick, D. G. Westfall, P. L. Chapman. Tissue nitrogen levels for dryland hard red winter wheat, Agronomy Journal, 1990, 82(3): 561-565. 
Bran and Luebbe. Bran+Luebbe Traacs 2000 continuous flow analyzer operation manual. MT9, GB-352-87A and GB-352-87E. Publication No. MT7-50EN-01. Bran+Luebbe GmbH, Norderstedt, Germany. 1996.

C. F. Jordan. Derivation of leaf area index from quality of light on the forest floor, Ecology, 1969, 50: 663-666

D. Smeal, H. Zhang. Chlorophyll meter evaluation for nitrogen management in corn, Communications in Soil Science and Plant Analysis, 1994, 25(9\&10): 1495-1503.

E. H. Tyner, J. W. Webb. The relation of corn yields to nutrient balance as revealed by leaf analysis, Journal of American Society of Agronmy, 1946, 38: 173-185.

E. Lukina, M. Stone, W. Raun. Estimating vegetation coverage in wheat using digital images, Journal of Plant Nutrition, 1999, 22(2): 341-350

F. J. Adamsen, J. Paul, J. Pinter, E. M. Barnes, R. L. LaMorte, G. W. Wall, S. W. Leavitt, B. A. 1999. Kimball. Measuring wheat senescence with a digital camera, Crop Science, 1999, 39(7): 719-724

I. Filla, L. Serrano, J. Serra, J. Peñuelas. Evaluating wheat nitrogen status with canopy reflectance indices and discriminant analysis, Crop Science, 1995, 35: 1400-1405

J. H. Wehrmann, C. Scharpf. M. Boehmer, J. Wollring. Determination of nitrogen fertilizer requirements by nitrate analysis of the soil and plant, In: Plant Nutrition 9th International Colloquium on Plant Nutrition, 1982, 202-208

J. W. Rouse, R. H. Has, J. A. Schell, D. W. Deering. Monitoring vegetation systems in the great plains with ERTS. Third ERTS Symposium, 1973, NASA SP-351, Vol. 1: 309-317. NASA, Washington, DC

L. L. Jia, X. P. Chen, F. S. Zhang, A. Buerkert, V. Römheld. Low altitude aerial photography for optimum N fertilization of winter wheat on the North China Plain, Field Crop Research, 2004a, 89: 389-395

L. L. Jia, X. P. Chen, F. S. Zhang, A. Buerkert, V. Römheld. Use of digital camera to assess the nitrogen status of winter wheat in the North China Plain, Journal of Plant Nutrtion, 2004b, 27(3): 441-450

M. Flowers, W. Randall, H. Ronnie. Quantitative approaches for using color infrared photography for assessing in-season nitrogen status in winter wheat, Agronmy Journal, 2003, 95: 1189-1200.

P. C. Scharf, J. A. Lory. Calibrating corn color from aerial photographs to predict sidedress nitrogen need, Agronomy Journal, 2002, 94: 397-404

R. F. Zhao, X. P. Chen, F. S. Zhang, H. L. Zhang, J. Schroder, and V. Roemheld. Fertilization and nitrogen balance in a wheat-maize rotation system in North China, Agronomy Journal, 2006, 98: 938-945

R. G. Zhen, R.A. Leigh. Nitrate accumulation by wheat (Triticum aestivum) in relation to growth and tissue N concentrations, Plant and Soil, 1990, 124: 157-160

R. H. Fox, W. P. Piekielek, K. M. Macneal. Using a chlorophyll meter to predict nitrogen fertilizer needs of winter wheat, Communications in Soil Science and Plant Analysis, 1994, 25(3\&4): 171-181.

R. P. Sripada, R. W. Heiniger, J. G. White, A. D. Meijer. Aerial color infrared photography for determining early In-season nitrogen requirements in corn, Agronomy Journal, 2006, 98: 968-977

R. P. Sripada, R. W. Heiniger, J. G. White, and R. Weisz. Aerial color infrared photography for determining late-season nitrogen requirements in corn, Agronomy Journal, 2005, 97 : $1443-1451$ 
S. Graeff, D. Steffens, S. Schubert. Use of reflectance measurements for the early detection of $\mathrm{N}, \mathrm{P}, \mathrm{Mg}$, and Fe deficiencies in Zea mays L, Journal of Plant Nutrition and Soil Science, 2001, 164: 445-450

SAS Institute. SAS/STAT user's guide, Version 8.1, SAS Inst., Cary, NC, 1998.

T. M. Blackmer, J. S. Schepers. Use of a chlorophyll meter to monitor nitrogen status and schedule fertigation for corn, Journal of Production Agriculture, 1995, 8(1): 56-60

T. M. Blackmer, J.S. Schepers. Aerial photography to detect nitrogen stress in corn, Journal of Crop Physiology, 1996, 148: 440-444

Xinping Chen, Hongjie Ji, Fusuo Zhang. The integrated evaluation on effect of excess fertilizer application on nitrate concentration of vegetable in Beijing. p. 270-277. In X. L. Li et al. (ed.) Fertilizing for sustainable production of high quality vegetables, Chinese Agriculture Publishing, Beijing, 2000 (In Chinese) 